\title{
Analysis of Constructive Errors in masonry confined in Highly Seismic Countries and Reinforcement of Walls with Galvanized Mesh
}

\author{
Wilder Goñi ${ }^{1,}$,, Nehemias Maquin ${ }^{1}$, José Rodríguez ${ }^{1}$ y Ennio Morán ${ }^{1}$ \\ ${ }^{1}$ Ingeniería Civil, Universidad Peruana de Ciencias Aplicadas, Lima, Perú
}

\begin{abstract}
In countries with high seismicity, such as those located in the Pacific belt of fire, great disasters are generated because many houses are not designed to resist seismic forces; this is because they have been built without any professional technical assistance and using low quality materials that make them more vulnerable to an earthquake. In developing countries such as Peru, the problem is recurrent, because more than $80 \%$ of homes are selfbuilt, causing construction errors that lead to $70 \%$ of these homes have no guarantees to withstand a major earthquake; the importance of solving this problem lies in the need to identify construction errors to study methods of reinforcement. This work investigates 371 houses of confined masonry, the most used construction system in South America, finding as a result that the most important construction error is the structural use of the tubular brick; in view of this, it is proposed to reinforce the walls with a construction system made up of tubular bricks reinforced with galvanized wire mesh to increase resistance and improve ductility.
\end{abstract}

\section{Introduction}

Due to the geodynamic behavior of the planet, large earthquakes of different magnitudes occur around the globe [1], generating many disasters. Although a greater disaster would be expected the greater the magnitude of the earthquake, the worst disasters in human history have been caused by earthquakes of lesser magnitude. The world's strongest earthquake on record occurred in Chile in 1960 with a magnitude of 9.5 and caused around 2,000 deaths, while the 2010 Haiti earthquake with a magnitude of less than 7 left 316,000 dead, 350,000 injured and more than 15 million victims [2]. This, it is inferred, is because developing countries do not have ant seismic housing and adequate construction methods and are exposed to a latent seismic hazard. For example, on the Pacific coast, exactly on the central coast of Peru, there is a greater than $70 \%$ probability that an earthquake with a magnitude greater than $8.8 \mathrm{Mw}$ will occur in the next 75 years [3].

However, $80 \%$ of the houses in this country are built without any professional assistance, causing construction errors [4] and more than $70 \%$ of the houses in its capital are not guaranteed to withstand a major earthquake [5]. Faced with this problem, there is a need to identify construction errors that can increase seismic vulnerability in confined masonry houses, structural system present in $43 \%$ of houses in Peru and the most used in South America [6].

The studies carried out in places where great disasters by earthquakes occurred, indicate that the main constructive errors causing the collapse of the houses of

\footnotetext{
${ }^{\mathrm{a}}$ Corresponding author: u201420161@upc.edu.pe
}

confined masonry were: Lack of integrity between walls and floor/ceiling diaphragms in the Gorkha earthquake Nepal, 2015 [7]; Absence of confining elements, lining of walls and a rigid diaphragm in the Simav earthquake Turkey, 2011 [8]; Masonry units made with inadequate resistances and permeabilities, Deficiency in the pouring of concrete and in the execution of walls in the Concepción earthquake - Chile, 2010 [9]; Low quality masonry units, Inadequate wall confinement, Absence of mooring beams and of a rigid diaphragm, and Lack and/or Discontinuity of columns in the earthquake of Ica - Peru, 2007 [10, 11]; and Inadequate wall confinement, poorly emptied concrete, Absence of a rigid diaphragm, Low wall density, Vertical discontinuity of walls and large ducts in the slabs in the earthquake of Ancash Peru, 1970 [11, 12]; and Inadequate wall confinement in the earthquake of Ancash - Peru, 1970 [11, 12].

This research identifies and classifies construction errors and analyzes their impact on confined masonry housing in areas of high seismic risk in a district of Lima, Peru. Then, the reinforcement with galvanized mesh of walls made with tubular bricks to increase their resistance and ductility is proposed as a solution to the most incident error.

\section{Methodology}

It describes the research process that has been carried out in this work, which includes the area of study, the identification and analysis of construction errors and the proposal for reinforcement. 


\subsection{Study area}

The investigation was carried out between January and March 2019 in the district of Villa El Salvador de LimaPeru, which presents a higher seismic risk because it is in a seismic zoning 4 according to Norm E. 030 of Seismic Resistant Design [13]. The study area includes sectors I and III, where 371 consolidated dwellings of 2 to 5 floors built under the confined masonry system were studied.

\subsection{Identification of errors}

A visual inspection of the dwellings is carried out in the field, equipped with a camera and a data sheet to record the construction errors causing the collapse of the dwellings in previous earthquakes. Then, in cabinet the constructive error of the data sheet is identified by each housing and it is verified with the image of the photograph.

\subsection{Error analysis}

This analysis was done under 2 modalities: a) quantitative, through a statistical analysis and Pareto Diagram to verify the frequency and accuracy of the most important constructive error, b) qualitative, through the Ishikawa Diagram and Content Analysis to pinpoint the causes, state, methods of prevention and rehabilitation, and solution to constructive errors.

\subsection{Proposed reinforcement of a tubular brick wall}

It is proposed to use a material of low cost and of easy access in the market, such is the case of the hexagonal mesh of galvanized wire of $3 / 4^{\prime \prime}$ of $\varnothing 1 \mathrm{~mm}$, as reinforcement of the walls of $47.5 \times 51 \mathrm{~cm}$ constructed with tubular bricks of $23 \times 11 \times 9 \mathrm{~cm}$.

\section{Results and validation}

\subsection{Study area}

Figure 1 shows the study area for sectors I (Zone 1) and III (Zone 2). In zone 1185 confined masonry dwellings were inspected and in zone 2186 dwellings of the same construction system.

\subsection{Identification of errors}

Table 1 identifies the construction errors observed in dwelling No. 3 in sector III (Zone 2) and Figure 2 shows the image of this dwelling.

\subsection{Analysis of construction errors}

\subsubsection{Quantitative analysis}

Table 2 presents the statistical analysis carried out, considering the total number of dwellings visited and the percentage frequency by number of floors. It shows that the highest percentage frequency is $48.25 \%$ for 2 -storey dwellings, followed by 3 -storey dwellings with $43.94 \%$.

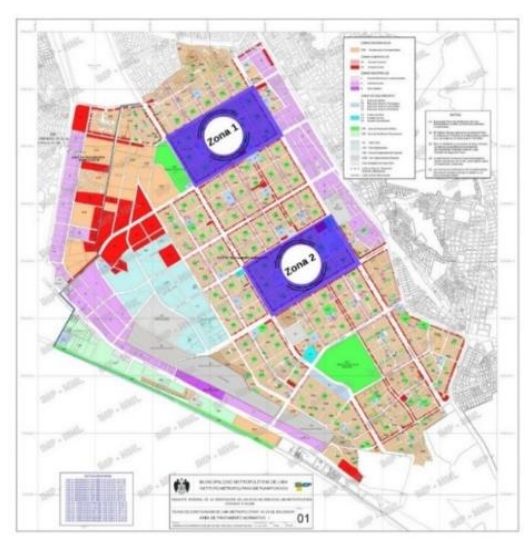

Figure 1. Areas of study in the district of Villa El Salvador.

Table 1. Constructive errors in housing $\mathrm{N}^{\circ} 3$ of sector III.

\begin{tabular}{|c|l|}
\hline Item & \multicolumn{1}{|c|}{ Constructive errors } \\
\hline A & Lack of continuity of vertical walls \\
\hline B & Absence of vertical confinement elements \\
\hline D & Absence of rigid diaphragm \\
\hline E & Lack of mooring beams \\
\hline G & Use of tubular brick for structural purposes \\
\hline
\end{tabular}

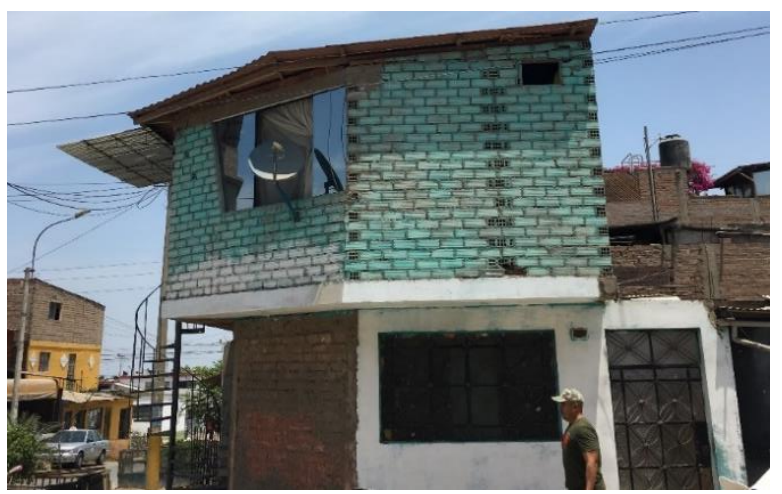

Figure 2. Photograph of housing $\mathrm{N}^{\circ} 3$ in sector III (Zone 2) of the district of Villa El Salvador.

Table 2. Distribution of dwellings according to the number of floors.

\begin{tabular}{|c|c|c|}
\hline $\begin{array}{c}\text { Number of } \\
\text { floors }\end{array}$ & $\begin{array}{c}\text { Number of } \\
\text { dwellings }\end{array}$ & $\begin{array}{c}\text { Percentage frequency } \\
\text { of dwellings }\end{array}$ \\
\hline 01 & 0 & $0.00 \%$ \\
\hline 02 & 179 & $48.25 \%$ \\
\hline 03 & 163 & $43.94 \%$ \\
\hline 04 & 27 & $7.28 \%$ \\
\hline 05 & 2 & $0.54 \%$ \\
\hline TOTAL & 371 & $100.00 \%$ \\
\hline
\end{tabular}

a) Statistical analysis 
This shows us that the place of study is mostly made up of 2 and 3-storey houses and they are the ones that present greater dangers in the event of a seismic event.

Table 3 shows the percentage of incidence in the 7 typical errors found in the dwellings. The main error is the use of tubular brick for structural purposes and has an incidence of $96.77 \%$, followed by an inadequate mortar joint between bricks, with an incidence of $91.37 \%$.

Table 3. Constructive errors identified in confined masonry dwellings.

\begin{tabular}{|c|c|c|c|}
\hline \multirow[b]{2}{*}{ Item } & \multicolumn{3}{|c|}{ General classification of construction errors } \\
\hline & $\begin{array}{c}\text { Type of construction } \\
\text { errors }\end{array}$ & $\begin{array}{c}\text { Number } \\
\text { of } \\
\text { dwellings }\end{array}$ & $\begin{array}{c}\% \\
\text { incidence }\end{array}$ \\
\hline A & $\begin{array}{l}\text { Lack of continuity of } \\
\text { vertical walls }\end{array}$ & 304 & $81.94 \%$ \\
\hline B & $\begin{array}{l}\text { Absence of vertical } \\
\text { confinement elements }\end{array}$ & 313 & $84.37 \%$ \\
\hline $\mathrm{C}$ & $\begin{array}{l}\text { Discontinuity } \\
\text { columns }\end{array}$ & 10 & $2.70 \%$ \\
\hline $\mathrm{D}$ & $\begin{array}{lll}\begin{array}{l}\text { Absence } \\
\text { diaphragm }\end{array} & \text { of } & \text { rigid } \\
\end{array}$ & 297 & $80.05 \%$ \\
\hline $\mathrm{E}$ & Lack of mooring beams & 205 & $55.26 \%$ \\
\hline $\mathrm{F}$ & $\begin{array}{l}\text { Inadequate mortar joint } \\
\text { between bricks }\end{array}$ & 339 & $91.37 \%$ \\
\hline G & $\begin{array}{l}\text { Use of tubular brick for } \\
\text { structural purposes }\end{array}$ & 359 & $96.77 \%$ \\
\hline
\end{tabular}

\section{b) Pareto Diagram}

Figure 3 shows the number of dwellings and their types of construction errors. It shows that the most important error to be resolved is the "G" which corresponds to the use of tubular brick for structural purposes. After the statistical classification of the constructive errors, an analysis of their hierarchy was carried out to determine the most important errors using Pareto's quality tool.

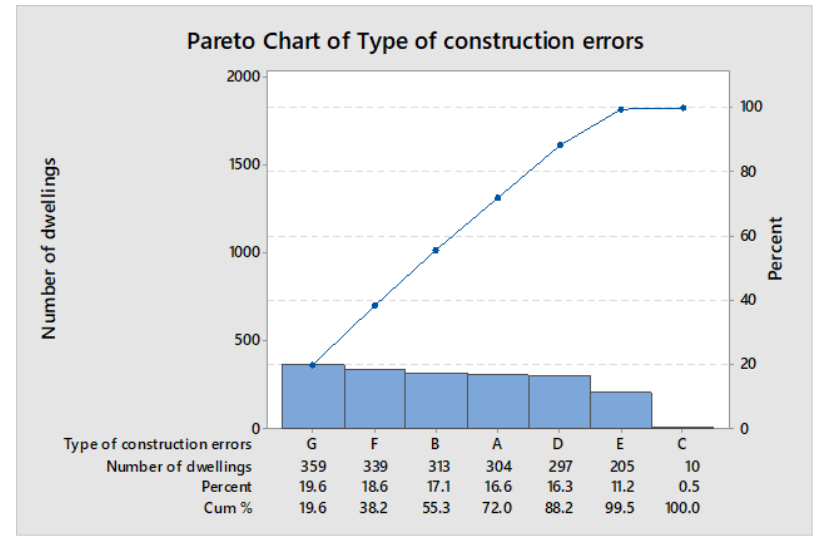

Figure 3. Pareto diagram for construction errors.

\subsubsection{Qualitative analysis}

a) Ishikawa diagram
Figure 4 shows the causes the use of tubular bricks for structural purposes. The main causes are: work environment, tubular brick, social environment and labor.

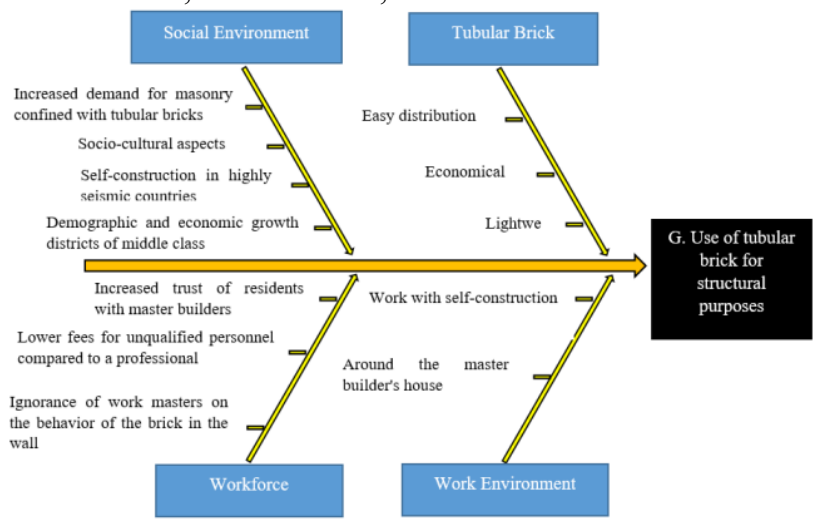

Figure 4. Cause - effect diagram for the most critical error.

\section{b) Content analysis}

\section{A. Lack of continuity of vertical walls}

Figure 5 shows that vertical loads are not transmitted directly to the ground, this generates cutting forces in the cantilevers as there is no support between slabs. Standard E.070 [13] indicates that confined masonry walls must be continuous because they perform a structural function of support and transmission of vertical loads. Standard [14] considers a confined wall to be structural when it is continuous from the foundation to its upper level.
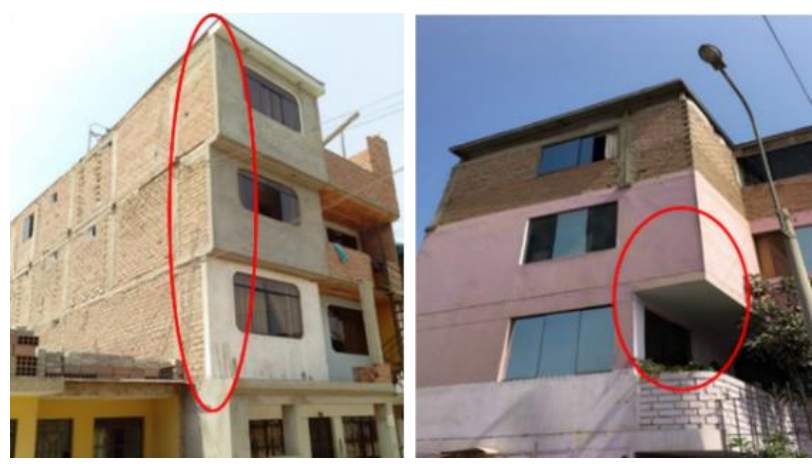

Figure 5. Discontinuity of walls in masonry dwellings.

\section{B. Absence of vertical confinement elements}

Figure 6 shows the non-confined walls at both ends, which have minimal resistance to lateral and oscillatory loads; and as their shear forces are more intense for the brick wall, the chances of failure and collapse increase. Confinement columns must be placed at the ends of structural walls, at intersections with other structural walls and in intermediate places at distances not greater than 35 times the effective wall thickness, 1.5 times the vertical distance between horizontal confinement elements or 4 meters [15]. Moreover, confined masonry walls may in no case have an unconfined length greater than 25 times their thickness [16]. 


\section{Discontinuity of columns}

Figure 7 shows that vertical loads are not adequately transmitted to the ground, generating a punching effect on the beams. Standard E.070 [13] requires the continuity of the columns. Confinement columns must be continuous from the foundation to the top of the wall and may be fabricated before or after the wall is erected [16].

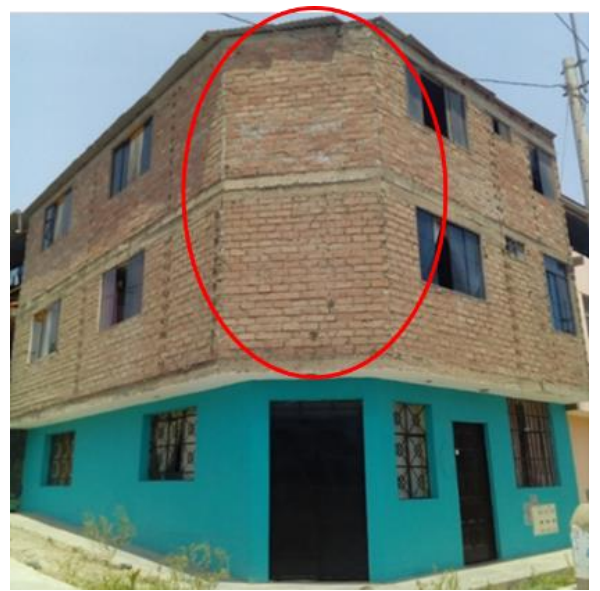

Figure 6. Absence of vertical confinement elements

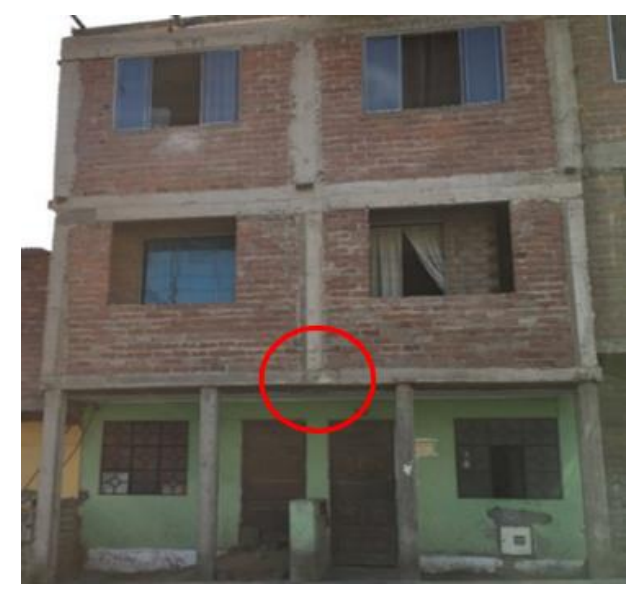

Figure 7. Column discontinuity in confined masonry dwellings.

\section{Absence of rigid diaphragm}

Figure 8 shows that the structural elements in the ends (columns or walls) do not receive the lateral loads, this generates unequal deformations. Standard [16] indicates the placement of horizontal confinement beams at the end of the wall and at vertical free distances not exceeding 25 times the thickness of the wall.
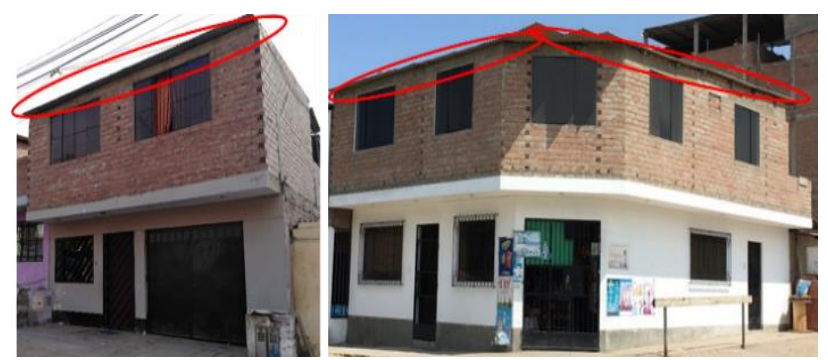

Figure 8. Absence of rigid diaphragm.

\section{E. Lack of mooring beams}

Figure 9 shows that the wall does not act as a whole, since it is not braced at its four ends (columns and beams). Standard E.070 [13] requires the complete confinement of masonry walls in order to increase the ductility of the system and reduce its fragility. The mooring beams must be placed at the level of the foundation, at the level of the mezzanine system and at the level of the deck level [15].

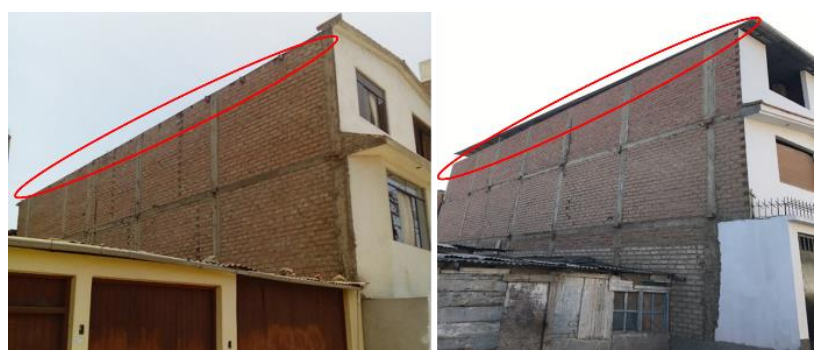

Figure 9. Lack of mooring beams.

\section{F. Inadequate mortar joint between bricks}

In Figure 10 (Right) you can see the separation between masonry units by the lack of connection of the brick with the mortar, this prevents the wall from responding evenly as a block. The thickness of the joint according to E.070 [13] must be a minimum of $10 \mathrm{~mm}$ and a maximum of 15 $\mathrm{mm}$. Standard [14] indicates that if mechanized manufacturing units are used, the thickness of horizontal joints shall not exceed $12 \mathrm{~mm}$ if horizontal reinforcement is placed in the joints, nor $10 \mathrm{~mm}$ without horizontal reinforcement; if artisanal manufacturing pieces are used, the thickness of joints shall not exceed $15 \mathrm{~mm}$; the minimum thickness shall always be $6 \mathrm{~mm}$ to ensure a good connection between bricks.
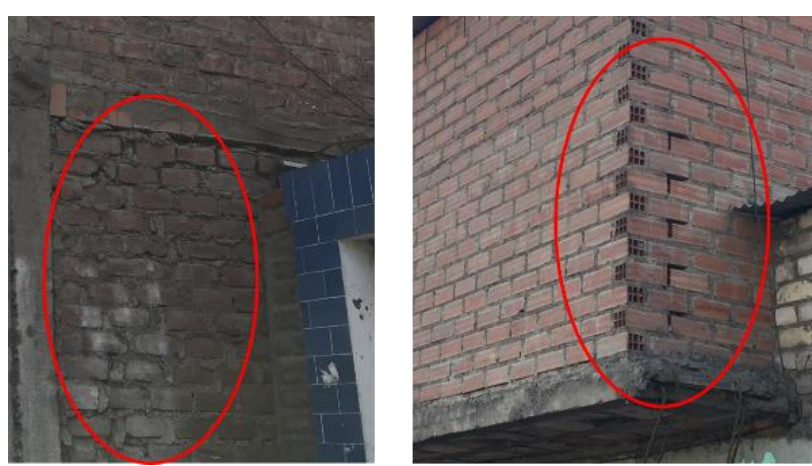

Figure 10. Inadequate mortar joint (Left) and absence of mortar (Right) between bricks.

\section{G. Use of tubular brick for structural purposes}

Figure 11 shows the wall made with a brick of low resistance and with many holes, which in the presence of a seismic movement do not support the loads of compression and traction, and the collapse of the wall occurs. For dwellings between 1 and 3 floors in seismic zonas greater than 3 , the use of solid industrial brick or alveolar brick filled with concrete is obligatory according to standard E.030 [13]. Tubular bricks with horizontal 
voids are accepted for confined masonry if their strength exceeds $3 \mathrm{MPa}$ [15].

In view of the above, a technical data sheet is drawn up on a construction error. Table 4 shows about the error in the use of tubular brick for structural purposes, elaborated based on the field work and the cabinet carried out.

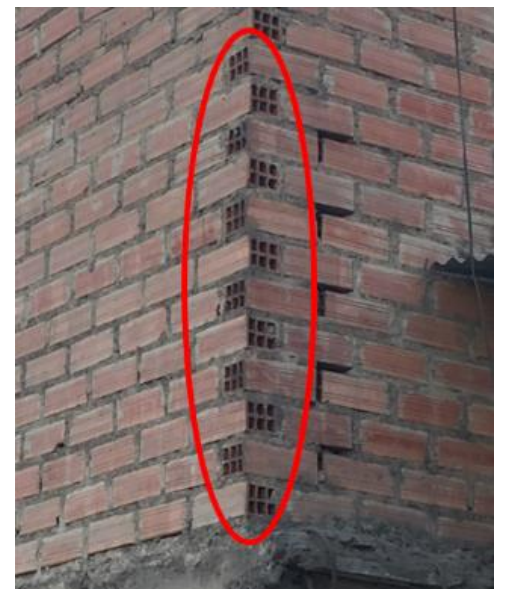

Figure 11. Tubular brick in a structural wall.

Table 4. Procedure for qualitative analysis of one of the constructive errors.

\begin{tabular}{|l|}
\hline Description \\
The walls of the houses \\
do not have elements of \\
confinement and the \\
only ones that are going \\
to support the cyclic \\
loads are the tubular \\
bricks, which are not \\
designed for such \\
purpose.
\end{tabular}

\subsection{Proposed reinforcement of a tubular brick wall}

\subsubsection{Background}

Peruvian technical standard E.070 of Masonry [13] indicates that clay tubular bricks may only be used in load-bearing walls in places where the seismic zoning is 1 and a maximum of two floors in a dwelling. However, many confined masonry housing constructions omit this information and misuse this type of brick.

\subsubsection{Basis}

The proposal is based on experimental researches on reinforcement carried out on walls with geogrids and metal meshes in order to increase the strength and ductility of the reinforced wall $[17,18]$.

\subsubsection{Reinforcement technique}

\section{-Description}

The tubular brick wall must be confined on both sides with the galvanized wire mesh and covered with 1: 4 dosing mortar (cement: fine sand). The mesh is fixed to the wall with alcayata nails and placed vertically so that the overlaps remain in the same direction. The meshes of both sides of the wall are connected with annealed wire No. 16 by means of a perforation in the wall. $1.5 \mathrm{~cm}$ of mortar cover should be considered, and the mesh must be embedded inside the mortar.

\section{-Materials}

- 3/4" galvanized wire hexagonal mesh (1 $\mathrm{mm}$ in diameter)

- $\quad$ Nail Alcayata $3.0 \times 25 \mathrm{~mm}$ for concrete

- $\quad$ Annealed wire No. 16

- $\quad$ Type I cement

- $\quad$ Fine sand

Table 5. Unit cost of reinforcement.

\begin{tabular}{|c|c|c|c|c|c|c|}
\hline Item & \multicolumn{6}{|c|}{ Reinforcement of wall with mesh of henhouse } \\
\hline $\begin{array}{l}\text { Perf } \\
\text { orm } \\
\text { ance }\end{array}$ & $\begin{array}{l}\mathrm{m}^{2} / \\
\text { Day }\end{array}$ & $\begin{array}{c}12.0 \\
0\end{array}$ & EQ. & 12.00 & $\begin{array}{l}\text { Cost } \\
\text { per } \\
\mathrm{m}^{2}\end{array}$ & $\begin{array}{c}S / . \\
26.61\end{array}$ \\
\hline \multicolumn{2}{|c|}{ Description } & UND & $\begin{array}{c}\text { Squa } \\
\mathrm{d}\end{array}$ & Quantity & $\begin{array}{c}\text { Price } \\
\mathrm{S} / .\end{array}$ & $\begin{array}{c}\text { Partial } \\
\mathrm{S} / .\end{array}$ \\
\hline \multicolumn{7}{|c|}{ Workforce } \\
\hline \multicolumn{2}{|c|}{ Foreman } & $\mathrm{HH}$ & 0.100 & 0.0667 & 20.67 & 1.38 \\
\hline \multicolumn{2}{|c|}{ Operator } & $\mathrm{HH}$ & 1.000 & 0.6667 & 17.52 & 11.68 \\
\hline \multicolumn{2}{|c|}{ Pawn } & $\mathrm{HH}$ & 0.500 & 0.3333 & 13.26 & 4.42 \\
\hline \multicolumn{6}{|c|}{+2} & 17.48 \\
\hline \multicolumn{7}{|c|}{ Materials } \\
\hline \multicolumn{2}{|c|}{$\begin{array}{c}\text { Alcayata Nails } \\
3.0 \times 25 \mathrm{~mm}\end{array}$} & $\mathrm{Kg}$ & & 0.0220 & 5.50 & 0.12 \\
\hline \multicolumn{2}{|c|}{ Fine Sand } & $\mathrm{m} 3$ & & 0.0236 & 50.00 & 1.18 \\
\hline \multicolumn{2}{|c|}{$\begin{array}{c}\text { Portland Cement } \\
\text { Type I ( } 42.50 \\
\text { Kg) }\end{array}$} & Bag & & 0.1190 & 22.20 & 2.64 \\
\hline \multicolumn{2}{|c|}{ Water } & $\mathrm{m} 3$ & & 0.0100 & 6.00 & 0.06 \\
\hline \multicolumn{2}{|c|}{$\begin{array}{c}\text { Galvanized } \\
\text { Hexagonal Wire } \\
\text { Mesh 3/4" }\end{array}$} & Und & & 1.0526 & 2.93 & 3.08 \\
\hline & & & & & & 7.08 \\
\hline \multicolumn{7}{|c|}{ Equipment } \\
\hline \multicolumn{2}{|c|}{ Manual tools } & $\begin{array}{c}\% \mathrm{M} \\
\mathrm{O}\end{array}$ & & 5.0000 & 17.48 & 0.87 \\
\hline \multicolumn{2}{|c|}{$\begin{array}{l}\text { Aluminum ruler } \\
1 \text { 1" } 4 \text { " x 8" }\end{array}$} & Und & & 0.0020 & 3.25 & 0.01 \\
\hline \multicolumn{2}{|c|}{ Metal scaffolding } & Day & 1.000 & 0.0833 & 14.00 & 1.17 \\
\hline
\end{tabular}




\section{- Cost}

Table 5 shows the unit cost per $\mathrm{m} 2$ of the proposal, which is $\mathrm{S} / .26 .62$ (7.88 USD).

\section{- Tests}

The tests were carried out in the Materials Resistance laboratory of the Peruvian University of Applied Sciences-Peru, using a Universal Instron model 3382 machine with a maximum test force of $100 \mathrm{kN}$. Simple (axial) compression trials were evaluated for the following cases: Case 1 - Tubular brick wall; Case 2 Tubular brick wall, reinforced with mesh on one side and covered with $1.5 \mathrm{~cm}$ mortar; and Case 3 - Tubular brick wall, reinforced with mesh on both sides and covered with $1.5 \mathrm{~cm}$ mortar.

Table 6 shows the axial compressive strength values obtained for each of the cases studied. For case 3 a higher resistance value is obtained, which corresponds to the developed proposal. In addition, the Post-test analysis showed an adhesion of the broken bricks to the reinforcing mesh. Although the bricks were broken, they were held together by the mesh. In this way, the wall had better ductile behavior.

Table 6. Simple compressive strength values of walls made of tubular bricks.

\begin{tabular}{|c|c|}
\hline Tests & Simple compressive strength \\
\hline CASE 01 & $\mathrm{f}_{\mathrm{m}}^{\prime}=10.35 \mathrm{Kg} / \mathrm{cm}^{2}(1.02 \mathrm{MPa})$ \\
\hline CASE 02 & $\mathrm{f}_{\mathrm{m}}^{\prime}=15.74 \mathrm{Kg} / \mathrm{cm}^{2}(1.54 \mathrm{MPa})$ \\
\hline CASE 03 & $\mathrm{f}_{\mathrm{m}}^{\prime}=15.85 \mathrm{Kg} / \mathrm{cm}^{2}(1.55 \mathrm{MPa})$ \\
\hline
\end{tabular}

\section{Conclusions}

The main construction errors identified in self-built confined masonry dwellings are the use of tubular brick for structural purposes and the inadequate mortar joint between bricks, both of which are not permitted in accordance with international seismic design standards.

The reinforcement proposal developed responds to an increase in strength and ductility in the wall and consists of confining the tubular brick wall on both sides with galvanized wire mesh covered with mortar.

\section{References}

1. J. Muñoz, (2004). Ingeniería Sismo resistente. Lima: Pontificia Universidad Católica del Perú.

2. British Broadcasting Corporation. (21 de setiembre de 2017). Los 10 terremotos más potentes y mortíferos de la historia en América Latina.

3. Instituto Nacional de Defensa Civil. (2017). Escenario Sísmico para Lima Metropolitana y Callao: Sismo 8.8 Mw.

4. Diario Gestión. (17 de marzo de 2017). ¿Cuántas viviendas son producto de la autoconstrucción y qué riesgos enfrentan?
5. Radio Programas del Perú - Noticias (RPP). (26 de setiembre de 2017). Capeco: El 70\% de viviendas en Lima son informales y vulnerables a un terremoto.

6. Universidad Nacional de Ingeniería-Centro Peruano Japonés de Investigaciones Sísmicas y Mitigación de Desastres. (2005). Construyendo edificaciones de albañilería con tecnologías apropiadas: Guía para la construcción con albañilería.

7. D. Dizhur, R. Dhakal, J. Bothara, \& J. Ingham (2016). Building Typologies and Failure Modes Observed in the 2015 Gorkha (Nepal) Earthquake. Bulletin of the New Zealand Society for Earthquake Engineering, 49(2), 211-232.

8. Yilmaz, N., \& Avsar, Ö. (2013). Structural damages of the May 19, 2011, Kütahya - Simav earthquake in turkey. Natural Hazards, 69(1), 981-1001. Doi: http://dx.doi.org/10.1007/s11069-013-0747-2

9. Alcaíno, P., Ruiz, T., Rivera, R. (2010). Análisis de daños y comportamiento de edificios de albañilería producto del sismo del 27 de febrero de 2010. Memoria Congreso Iberomet XI, X CONAMET/SAM.

10. Quiun, D. \& San Bartolomé, A. (2010). El terremoto de 2007 en Perú y las normas de albañilería y adobe. En: ASAIE. XXIV Jornadas Sudamericanas de Ingeniería Estructural

11. Kuroiwa, J., Torrealva, D., San Bartolomé, A. y Zavala, C. (2009). Manual para la reparación y reforzamiento de viviendas de albañilería confinada dañada por sismos-tipología de daños.

12. San Bartolomé, A. (1994). Construcciones de Albañilería: Comportamiento sísmico y diseño estructural. Lima: PUCP

13. Ministerio de Vivienda, Construcción y Saneamiento. (8 de junio de 2006). Reglamento Nacional de Edificaciones. [Decreto Supremo N ${ }^{\circ}$ 011-2006VIVIENDA].

14. Sociedad Mexicana de Ingeniería Estructural. [México]. Normas técnicas complementarias para diseño y construcción de estructuras de mampostería.

15. Gobierno Nacional [Colombia]. (2010). Decreto $\mathrm{N}^{\circ}$ 926. Reglamento colombiano de Construcción Sismo resistente.

16. Ministerio de Desarrollo Urbano y Vivienda [Ecuador]. (2014). Norma Ecuatoriana de la Construcción.

17. Torrealva, D. (s.f.). Refuerzo de muros y tabiques de albañilería con mallas de polímero

18. Cevallos, O., \& Víctor, D. (2018). Reforzamiento estructural de muros de ladrillos pandereta con mallas para tarrajeo y electrosoldada. Tesis de licenciatura, PUCP, Facultad de Ciencias e Ingeniería. Lima, Perú. 